\title{
A Case Report of Double Malignancy
}

\author{
T. Rathnaganpathi ${ }^{1}$, Siddharth $^{2 *}$, Barathiraja $^{3}$ and Ravi Shankar ${ }^{4}$ \\ Department of General Surgery, Sree Balaji Medical College and Hospital, \\ Chennai (TN), India \\ *Corresponding author
}

\section{A B S T R A C T}

\begin{tabular}{|l|}
\hline Ke y w o r d s \\
Double malignancy, \\
Polypoid lesion, \\
MRI, \\
Ulceroproliferative \\
growth
\end{tabular}

\section{Introduction}

A 65 year old female hailing from thiruvanamalai came with the complaints of upper abdominal pain for three months on and off. Pain was Sudden onset, intermittent in nature, not radiating and no Aggravating factor, relives spontaneously. H/o vomiting + [2 episodes] mostly food as contains, no h/o nausea. H/o Difficulty in swallowing solid food > liquid food. h/o loss of appetite + , No h/o loss of weight, h/o constipation+, h/o tarry black colored stools + , h/o burning micturition ,$+ \mathrm{h} / \mathrm{o}$ increase in micturition and no other significant symptom. No history of smoking or alcohol and no family history. Results of physical examination were normal. On routine investigation renal function test were elevated. Ultrasonogram suggestive of - polypodial lesion over the bladder / bilateral medico renal disease. On upper endoscopy suggestive of ulceroproliferative growth in body involving incisura and antrum along the lesser curvature ( hown in Fig-1) were biopsy taken and shows infiltrating adenocarcinoma. MRI scan suggestive of Circumferential wall thickening seen involving the lesser curvature and posterior wall in the distal body, incisura and antrum which is abutting the pancreatic head, neck and proximal body with no fat plane in 
between - gastric malignancy may be consider, with chronic kidney disease, small mildly T2 hypo intense polypoid lesion seen in the posterior wall of the urinary bladder in the midline. pt underwent TURBT(Transurethral Resection of Bladder Tumor) (shown in Fig 2) with Sub total gastrectomy (shown in Fig 3) with jejunojejunostomy with feeding jejunostomy. Biopsy of the specimen suggestive of Asubtotal gastrectomy specimen suggest infiltrative adenocarcinoma and BTransurethral Resection of Bladder Tumor suggest transitional cell carcinoma (shown in Fig. 4). Post operative period was uneventful. Patient under regular follow up.

\section{Results and Discussion}

The first systematic study of this type of multiple malignancies phenomenon was published in the 1930s by Warren and Gates. These authors proposed the first working definition of multiple primary neoplasms: (1) both tumors should be confirmed histologically as malignant; (2) each cancer must be anatomically separate and distinct; and (3) the second tumor must not be a recurrence or metastasis of the first cancer. Multiple tumors may develop synchronously or metachronously. The phenomenon of multiple primary neoplasms is increasingly being discussed in the literature due to the increased survival time of cancer patients after treatment and because of advances in diagnostic methods. It is estimated that multiple neoplasms affect about $10 \%$ of all cancer patients[1-4]. The most common types of synchronous and metachronous neoplasms were colorectal cancer, followed by cancers of the lung, breast, and prostate. Our data seems to be similar to the findings of others, who also reported that colorectal cancer is the most frequent neoplasm in GC patients with multiple malignancies $[6,8,10,17,20,23]$, followed by lung, uterus, breast, and prostate cancers $[6,8,10,11,17,24]$.

Table.1 Sites of additional synchronous and metachronous cancers in gastric cancer patients $\mathrm{n}(\%)$

\begin{tabular}{|l|c|c|c|}
\hline \multirow{2}{*}{ Site } & No. tumors & Metachronous & Synchronous \\
\cline { 2 - 4 } & $\boldsymbol{n = 6 2}$ & $\boldsymbol{n}=\mathbf{3 9}$ & $\boldsymbol{n}=\mathbf{2 3}$ \\
\hline Colorectal & $17(27.4)$ & $7(17.9)$ & $10(43.5)$ \\
\hline Lung & $9(14.5)$ & $5(12.8)$ & $4(17.4)$ \\
\hline Breast & $8(12.9)$ & $7(17.9)$ & $1(4.3)$ \\
\hline Prostate & $7(11.3)$ & $4(10.3)$ & $3(13.1)$ \\
\hline Lymphoma & $4(6.5)$ & $2(5.1)$ & $2(8.7)$ \\
\hline Skin & $4(6.5)$ & $2(5.1)$ & $2(8.7)$ \\
\hline Krinary bladder & $3(4.9)$ & $3(7.7)$ & - \\
\hline Larynx & $2(3.2)$ & $1(2.6)$ & $1(4.3)$ \\
\hline Non Hodgkin Lymphoma & $2(3.2)$ & $2(5.1)$ & - \\
\hline Head & $2(3.2)$ & $2(5.1)$ & - \\
\hline Ovary & $1(1.6)$ & $1(2.6)$ & - \\
\hline Pancreas & $1(1.6)$ & $1(2.6)$ & - \\
\hline Uterus & $1(1.6)$ & $1(2.6)$ & - \\
\hline
\end{tabular}




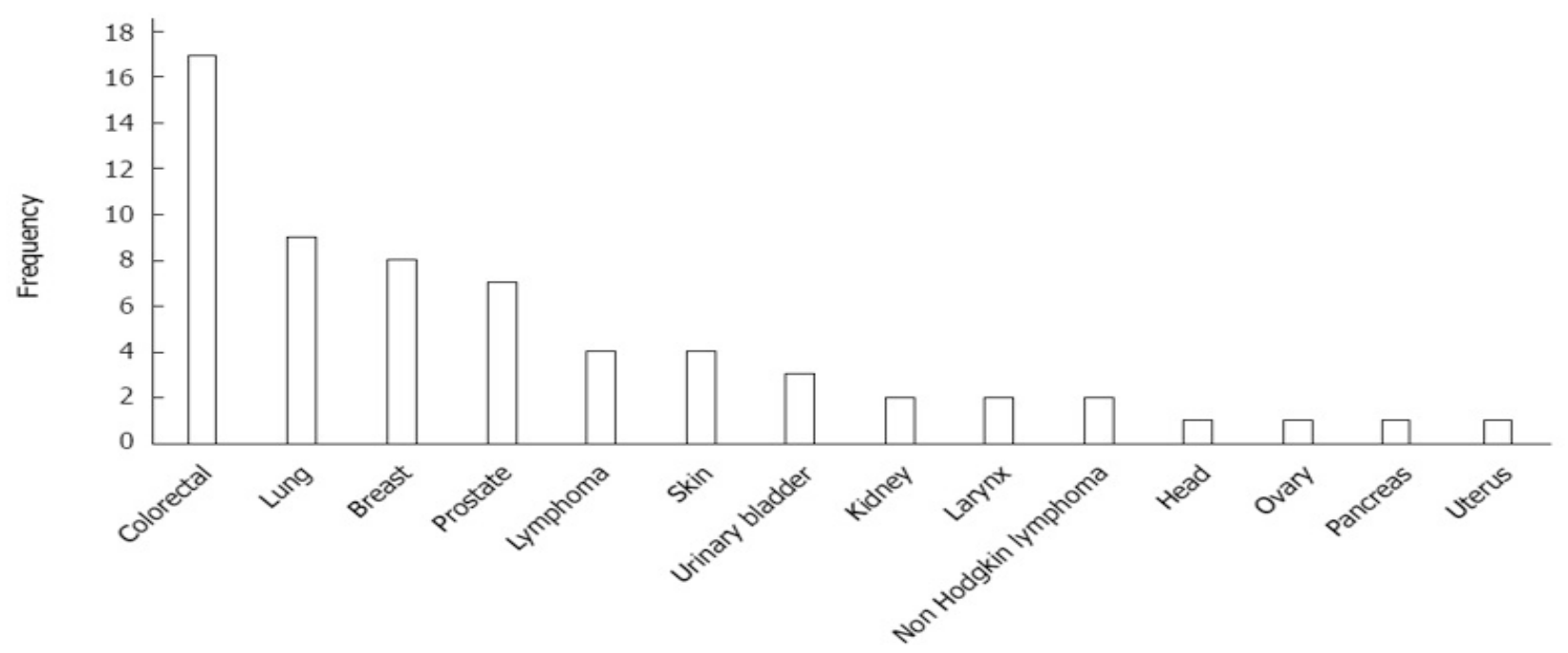

Fig.1\&2 UGI scopy shows ulceroproliferative growth in body \& Cystoscopy image of the polypoid growth in the urinary bladder
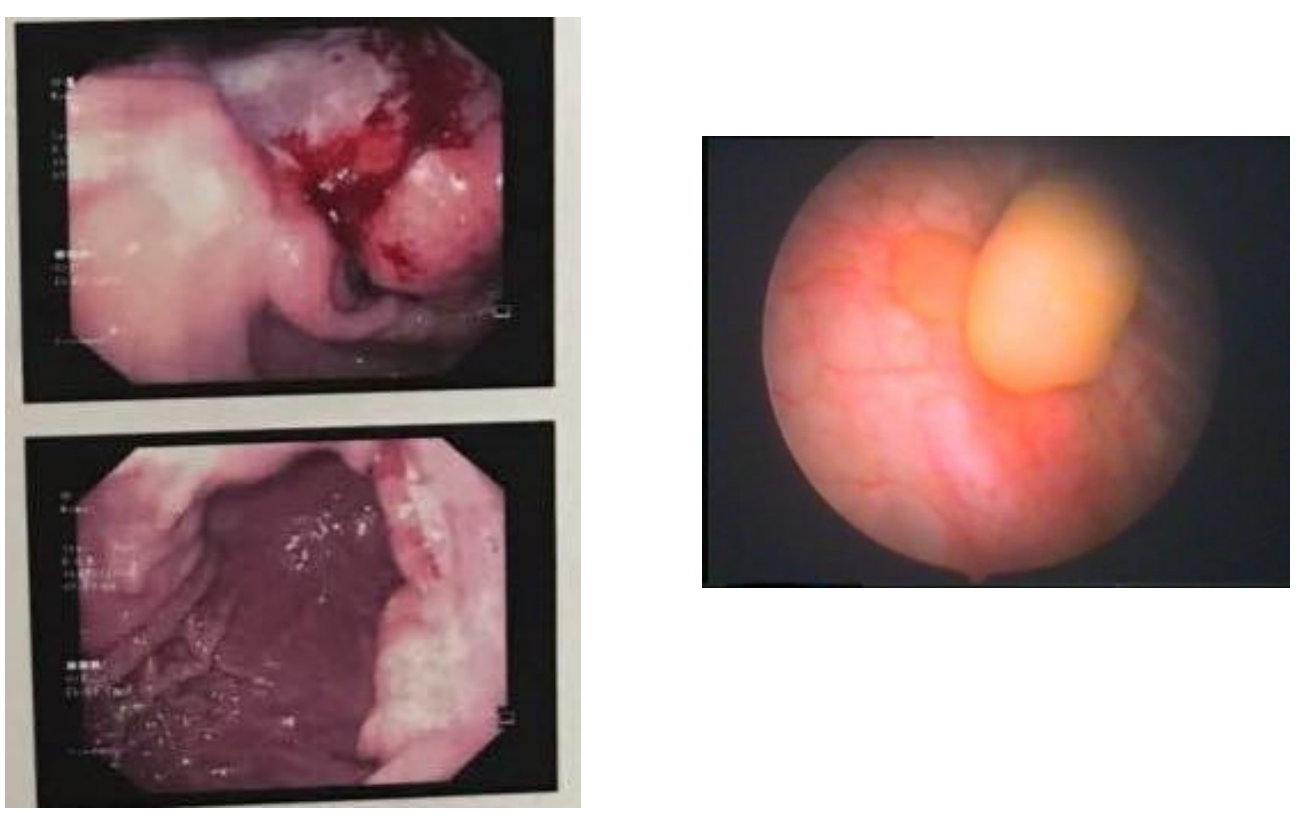

Fig.3\&4 Sub total gastrectomy \& histopathology of growth in bladder - transitional cell carcinoma
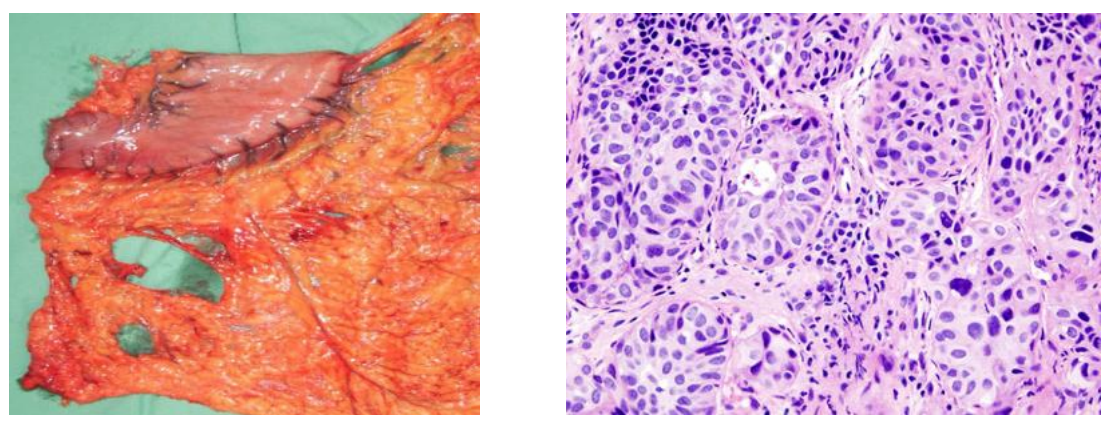
An analysis of the site distribution in the 58 GC patients with multiple cancers $(n=62)$ showed that the most common site was colorectal $(n=17,27.4 \%)$, followed by lung $(n=9,14.5 \%)$, breast $(n=8,12.9 \%)$, and prostate $(n=7,11.3 \%)$ (Figure -1$)$. In men, the most common site was colorectal $(n=10)$, lung $(n=8)$, and prostate $(n=7)$. In women, the most common site was breast $(n=8)$ and colorectal $(n=7)$. Among the 23 synchronous tumors, the most common primary sites were colorectal $(n=10,43.5 \%)$, lung $(n=4$, $17.4 \%)$, and prostate $(n=3,13.1 \%)$. For the 39 metachronous cancers, the dominant types were colorectal cancer $(n=7,17.9 \%)$ and breast cancer $(n=7,17.9 \%)$, followed by lung cancer $(n=5,12.8 \%)$ (Table 1$)$.

In women, lung cancer is the second most common cancer after breast cancer, while colon cancer is the fifth and rectal is the eighth most common cancer (according to registration of new cases)[25]. Ikeda et al., [17] found that patients with a second tumor tended more frequently to be males and elderly than those without a second tumor. Eom et al., [8] indicated that the mean age of patients and the proportion who had early GC were both higher in patients with a second cancer than in those without.

In our rare case combination of urinary bladder cancer and gastric carcinoma, not associated with any known syndromes. This requires multidisciplinary approach with timely interventions. Patients underwent psycholological support as burden of two malignancies. It is a challenge to treat two different malignancies together without any known standard of care. Our patient was treated for each tumor according to its own stage with multimodality approach. Some evidence for management of this type of condition needs to be available in literature to help treat patients in situation like ours.

\section{References}

1.Warren S, Gates O. Multiple primary malignant tumors: a survey of the literature and statistical study. Am J Cancer 1932; 16: 1358-1414

2.Neugut AI, Robinson E. Multiple primary neoplasms. Cancer J 1992; 5: 245-248

3.Luciani A, Ascione G, Marussi D, Oldani S, Caldiera S, Bozzoni S, Codecà C, Zonato S, Ferrari D, Foa P. Clinical analysis of multiple primary malignancies in the elderly. Med Oncol 2009; 26: 27-31 [PMID: 18483884 DOI: $10.1007 / \mathrm{s} 12032-008-9075-\mathrm{x}]$

4.Frödin JE, Ericsson J, Barlow L. Multiple primary malignant tumors in a national cancer registry--reliability of reporting. ActaOncol 1997; 36: 465-469 [PMID: 9292741 DOI: $\quad 10.3109 / 0$ 2841869709001300]

5.Hiyama T, Hanai A, Fujimoto I. Second primary cancer after diagnosis of stomach cancer in Osaka, Japan. Jpn J Cancer Res 1991; 82: 762-770 [PMID: 1908843]

6.Lee JH, Bae JS, Ryu KW, Lee JS, Park SR, Kim CG, Kook MC, Choi IJ, Kim YW, Park JG, Bae JM. Gastric cancer patients at high-risk of having synchronous cancer. World J Gastroenterol 2006; 12: 2588-2592 [PMID: $16688807 \quad$ DOI: 10.3748/wjg.v12.i16.2588]

7.Park YK, Kim DY, Joo JK, Kim JC, Koh YS, Ryu SY, Kim YJ, Kim SK. Clinicopathological features of gastric carcinoma patients with other primary carcinomas. Langenbecks Arch Surg 2005; 390: 300-305 [PMID: 15599757 DOI: 10.1007/ s00423-004-0525-4]

8.Eom BW, Lee HJ, Yoo MW, Cho JJ, Kim WH, Yang HK, Lee KU. Synchronous and metachronous cancers in patients with gastric cancer. J SurgOncol 2008; 
98: 106-110 [PMID: 18452218 DOI: 10.1002/jso.21027]

9.Lundegårdh G, Hansson LE, Nyrén O, Adami HO, Krusemo UB. The risk of gastrointestinal and other primary malignant diseases following gastric cancer. ActaOncol 1991; 30: 1-6 [PMID: 2009177]

10.Dinis-Ribeiro M, Lomba-Viana H, Silva R, Moreira-Dias L, Lomba-Viana R. Associated primary tumors in patients with gastric cancer. J ClinGastroenterol 2002; 34: 533-535 [PMID: 11960064 DOI:

10.1097/01.MCG..0000012424.19363.C D]

11.Wu CW, Lo SS, Chen JH, Hsieh MC, Li AF, Lui WY. Multiple primary cancers in patients with gastric cancer. Hepatogastroenterology 2006; 53: 463 467 [PMID: 16795993]

12.Buyukasik O, Hasdemir AO, Gulnerman Y, Col C, Ikiz O. Second primary cancers in patients with gastric cancer. RadiolOncol 2010; 44: 239-243 [PMID: 22933922 DOI: $10.2478 /$ v10019-0100048-2]

13. Green PH, O'Toole KM, Weinberg LM, Goldfarb JP. Earlygastriccancer. Gastroenterology 1981; 81: 247-256 [PMID: 7239133]

14.Ikeguchi M, Ohfuji S, Oka A, Tsujitani S, Maeda M, Kaibara N. Synchronous and metachronous primary malignancies in organs other than the stomach in patients with early gastric cancer. Hepatogastroenterology 1995; 42: 672676 [PMID: 8751233]

15.Bozzetti F, Bonfanti G, Mariani L, Miceli R, Andreola S. Early gastric cancer: unrecognized indicator of multiple malignancies. World J Surg 2000; 24: 583-587 [PMID: 10787081 DOI: 10.1007/s002689910097]

16. Kim JH, Rha SY, Kim C, Kim GM, Yoon SH, Kim KH, Kim MJ, Ahn JB, Chung
HC, Roh JK, Kim HS. Clinicopathologic features of metachronous or synchronous gastric cancer patients with three or more primary sites. Cancer Res Treat 2010; 42: 217-224 [PMID: 21253324 DOI: 10.4143/ crt.2010.42.4.217]

17.Ikeda Y, Saku M, Kawanaka H, Nonaka M, Yoshida K. Features of second primary cancer in patients with gastric cancer. Oncology 2003; 65: 113-117 [PMID: 12931016 DOI: 10.1159/000072335]

18 .Lauren P. The two histological main types of gastric carcinoma: diffuse and socolled intestinal type carcinoma. An attempt at histo-clinical classification. Acta Path et MicrobiolScandinav 1965; 64: 31-49

19.Muela Molinero A, Jorquera Plaza F, Ribas Ariño T, Malagón Rojo R, Espinel Diez V, Ballesteros del Río B, OlcozGoñi JL, Santos Calderón JA. Multiple malignant primary neoplasms in patients with gatric neoplasms in the health district of León. RevEspEnfermDig 2006; 98: 907-916 [PMID: 17274696 DOI: 10.432/S113001082006001200003]

20.Kim JY, Jang WY, Heo MH, Lee KK, Do YR, Park KU, Song HS, Kim YN. Metachronous double primary cancer after diagnosis of gastric cancer. Cancer Res Treat 2012; 44: 173-178 [PMID: 23091443

DOI:

10.4143/crt.2012.44.3.173]

21.Ikeda Y, Saku M, Kishihara F, Maehara Y. Effective followup for recurrence or a second primary cancer in patients with early gastric cancer. Br J Surg 2005; 92: 235-239 [PMID: 15609385 DOI: 10.1002/bjs.4758]

22. Itoh $\mathrm{H}$, Oohata $\mathrm{Y}$, Nakamura $\mathrm{K}$, Nagata $\mathrm{T}$, Mibu R, Nakayama F. Complete tenyear postgastrectomy follow-up of early gastric cancer. Am J Surg 1989; 158: 
14-16 [PMID: 2742043 DOI: 10.1016/0002-9610(89)90305-X]

23.Furukawa $H$, Hiratsuka $M$, Iwanaga $T$, Imaoka $\mathrm{S}$, Kabuto $\mathrm{T}$, Ishikawa $\mathrm{O}$, Sasaki Y, Kameyama M, Ohigashi H, Nakamori S. Treatments for second malignancies after gastrectomy for stomach cancer. Hepatogastroenterology 1996; 43: 194198 [PMID: 8682461]

24.Bae JS, Lee JH, Ryu KW, Kim YW, Bae JM. Characteristics of synchronous cancers in gastric cancer patients. Cancer Res Treat 2006; 38: 25-29 [PMID: 19771255 DOI: 10.4143/ crt.2006.38.1.25]

25.Didkowska J, Wojciechowska U, Zatoński W. Cancers in Poland in 2009. Warsaw 2011; 60-61

26.Ławniczak M, Starzyńska T. [Helicobacter pylori infection in gastric cancer patients]. Pol MerkurLekarski 2002; 13: 103-106 [PMID: 12420337]

27.AIRD I, BENTALL HH, ROBERTS JA. A relationship between cancer of stomach and the $\mathrm{ABO}$ blood groups. $\mathrm{Br}$ Med J 1953; 1: 799-801 [PMID: 13032504]

28.Edgren G, Hjalgrim H, Rostgaard K, Norda R, Wikman A, Melbye M, Nyrén O. Risk of gastric cancer and peptic ulcers in relation to $\mathrm{ABO}$ blood type: a cohort study. Am J Epidemiol 2010; 172: 1280-1285 [PMID: 20937632 DOI: 10.1093/ aje/kwq299]

29. Gong Y, Yang YS, Zhang XM, Su M, Wang J, Han JD, Guo MZ. ABO blood type, diabetes and risk of gastrointestinal cancer in northern China. World J Gastroenterol 2012; 18 : 563-569 [PMID: 22363124 DOI: 10.3748/wjg.v18.i6.563]

30.Wang Z, Liu L, Ji J, Zhang J, Yan M, Zhang J, Liu B, Zhu Z, Yu Y. ABO Blood Group System and Gastric Cancer: A CaseControl Study and Meta-Analysis. Int J MolSci 2012; 13: 13308-13321 [PMID: 23202954 DOI: 10.3390/ijms131013308]

31.Wolpin BM, Chan AT, Hartge P, Chanock SJ, Kraft P, Hunter DJ, Giovannucci EL, Fuchs CS. ABO blood group and the risk of pancreatic cancer. J Natl Cancer Inst 2009; 101: 424-431 [PMID: 19276450 DOI: $10.1093 /$ jnci/djp020]

32.Stamatakos M, Kontzoglou K, Safioleas P, Safioleas C, Manti C, Safioleas M. Breast cancer incidence in Greek women in relation to $\mathrm{ABO}$ blood groups and $\mathrm{Rh}$ factor. IntSeminSurgOncol 2009; 6: 14 [PMID: 19689811 DOI: $10.1186 / 1447-7800-6]$

\section{How to cite this article:}

Rathnaganpathi, T., Siddharth, Barathiraja and Ravi Shankar. 2019. A Case Report of Double Malignancy. Int.J.Curr.Microbiol.App.Sci. 8(03): 2484-2489.

doi: https://doi.org/10.20546/ijcmas.2019.803.294 